\title{
Environmental Contamination by Industrial Effluents and Sludge Relative to Heavy Metals
}

\author{
S. K. Al-Musharafi' ${ }^{1}$, I. Y. Mahmoud ${ }^{2}$, S. N. Al-Bahry ${ }^{3}$ \\ ${ }^{1}$ Department of Applied Biotechnology, Sur College of Applied Sciences, Sur, Oman \\ ${ }^{2}$ Department of Biological Sciences and Chemistry, University of Nizwa, Nizwa, Oman \\ ${ }^{3}$ Department of Biology, College of Science, Sultan Qaboos University, Muscat, Oman \\ Email: salma.sur@cas.edu.om
}

Received December 2013

\begin{abstract}
Oman is located in the tropic of Cancer with extremely hot temperatures ranging between $15^{\circ} \mathrm{C}$ $-25^{\circ} \mathrm{C}$ in winter and $30-48^{\circ} \mathrm{C}$ in the summer with low rainfall. Most of the water source is desalinated seawater. Recycling of sewage effluent is a common practice used for farming, public parks and industry. The dried sludge product is used as fertilizer. The highly concentrated sludge with heavy metals is either incinerated or buried in landfills. Heavy metals were analyzed and compared in treated sewage effluent (TSE), slurry sludge, dried sludge, landfill and underground water. Heavy metal concentrations were analyzed using the inductive coupled plasma optical emission spectrometer (ICP-OES). All samples contained the same heavy metals with different concentrations. The heaviest concentrations were $\mathrm{Zn}, \mathrm{Cr}, \mathrm{Cu}$ and $\mathrm{Ni}$ with traces of $\mathrm{V}, \mathrm{Cd}, \mathrm{Pb}$ and $\mathrm{Ba}$. TSE and sludge were the main sources of landfill and underground water contamination. Due to water evaporation, heavy metals concentrations in sludge were higher compared to TSE and underground water. Dried sludge and landfill contained higher concentrations than the others. Based on this investigation, it appears that the source of heavy metals is from TSE originated mainly in industries. If the infiltration of heavy metals to underground water continues, it will be a serious environmental and health problem in the future.
\end{abstract}

\section{Keywords}

Contamination; Heavy Metals; Treated Sewage Effluent; Sludge; Landfill; Underground Water

\section{Introduction}

Due to low rainfall in Oman, seawater desalination is the main source of potable water. Sewage water is reclaimed through sewage treatment plants established in main metropolitan areas in Oman. Treated sewage effluent (TSE) is predominantly used for irrigation, which consequently is the major source of heavy metal contamination. In Oman, during the last few years, there has been a steady increase in heavy metal concentrations at 
different habitats (Al-Bahry et al., 2011, Al-Musharafi et al., 2012, 2013a, 2013b, 2013c; Al-Rawahi et al., 2007). It was also reported that heavy metal concentration in the three sewage treatment plants (STP) was related to heavy metals in sludge irrigated with TSE (Al-Musharafi et al., 2012).

The accumulation of heavy metals in aquatic and terrestrial habitats is dramatically on the rise, especially in the industrial countries of the world. The heavy metal contamination ends up infiltrating ecological niches such as soil which consequently reaches underground water and wells. In addition, heavy metals can also contaminate agriculture fields, rivers and seas (Al-Bahry et al., 2011; Al-Musahrafi et al., 2013c; Al-Rawahi, 2007). Heavy metals in some sectors of the world are contaminating wild life, crops, domestic animal and humans (Fent, K., 1996; Harper et al., 2007; Jeffree et al., 2006; Kojadinovic et al., 2007; Kannan et al., 2006; Mapanda et al., 2007; Storelli et al, 2008; Zauke et al., 2003). Heavy metal contamination might develop into severe health problems which can lead to serious diseases (Mishra et al., 2010).

Some heavy metals are toxic to animals and plants because of their affinity to bind with proteins (Al-Musharafi et al., 2012). Heavy metal accumulation can be a factor in poisoning some organisms which in turn can be fatal (Harper et al., 2007; Kojadinovic et al., 2007; Storelli et al., 2008; Kannan et al., 2006; Jeffree et al., 2006; Zauke et al., 2003). However, some heavy metals such as $\mathrm{Co}, \mathrm{Cu}, \mathrm{Mn}$ and $\mathrm{Zn}$ are essential for the enzymatic reactions but they can be toxic at high concentrations (Fent et al., 1996).

Rules and regulations must be set internationally concerning heavy metals usage in industry and agriculture. International committees must be organized to set up regulations controlling and minimizing heavy metal contamination of the environment.

The aim of this investigation is to evaluate the impact of heavy metal contamination from sludge generated from industrial source STP, buried in landfills and to assess its contamination of underground water which may affect environment and human health.

\section{Materials and Methods}

The study area is located near the industrial sector in Oman. Samples were collected from the STPs recycled industrial effluents. TSE and sludge were collected twice monthly during March through September. During the study period, temperature ranged between $30^{\circ} \mathrm{C}-48^{\circ} \mathrm{C}$, with no precipitation.

One liter effluent and underground water samples were collected for heavy metal analysis (Carter et al., 2000). Samples were preserved in a cooler at $10^{\circ} \mathrm{C}$ (APHA, AWWA, \& WEP, 1998).

Sterile plastic bags were used to collect sludge and landfill samples. The samples were dried at $105^{\circ} \mathrm{C}$ for $3 \mathrm{~h}$. $0.2 \mathrm{~g}$ of samples were placed in perfluoroalkoxy polymer container and mixed with concentrated nitric acid (4 $\mathrm{ml})$ and of hydrofluoric acid $(0.5 \mathrm{ml})$, and heated in a microwave for $40 \mathrm{~min}$. The samples were diluted to 100 $\mathrm{ml}$ water. All solutions from the samples were diluted to a final concentration of $1 \mathrm{~g} / \mathrm{l}$ (Moor et al., 2001).

Underground water and TSE samples were filtered and analyzed for $\mathrm{Ba}, \mathrm{Cd}, \mathrm{Cr}, \mathrm{Cu}, \mathrm{Ni}, \mathrm{Pb}, \mathrm{V}$ and $\mathrm{Zn}$ using inductively coupled plasma optical emission spectrometer (ICP-OES) type Perkin Elmer 3300 DV ICP (USA). Blank, certified control samples were used as references.

\section{Results}

Heavy metals concentrations in TSE were slightly lower than in sludge and landfill but higher than the underground water (Figures 1-5). Analyses of heavy metals in all samples revealed that the major metals in order of their abundance were $\mathrm{Zn}, \mathrm{Cr}, \mathrm{Cu}$, Ni followed by traces of $\mathrm{V}$ and $\mathrm{Cd}$ (Figure 2).

When the slurry sludge was desiccated and the water evaporated completely, the concentrations of the same metals increased because of the decrease in sludge volume (Figure 3). When the heavy metals in the dry sludge and landfills were compared, the dry sludge had a slightly lower concentration (Figure 4).

The underground water contaminated by TSE and sludge showed lower concentration than the rest of the study samples (Figure 5).

\section{Discussion}

In an arid region, such as Oman, the water resource is inadequate which forces the authorities to establish the desalination program throughout the country. In addition, reclaimed sewage water is on the increase to be used in farming and industrial sectors. As a result of this practice, there is a wide spread of heavy metals throughout 


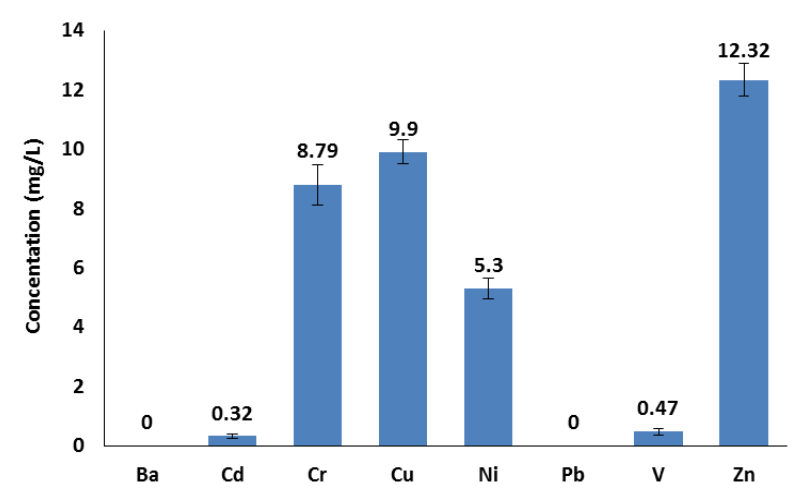

Figure 1. Heavy metal concentration in TSE.

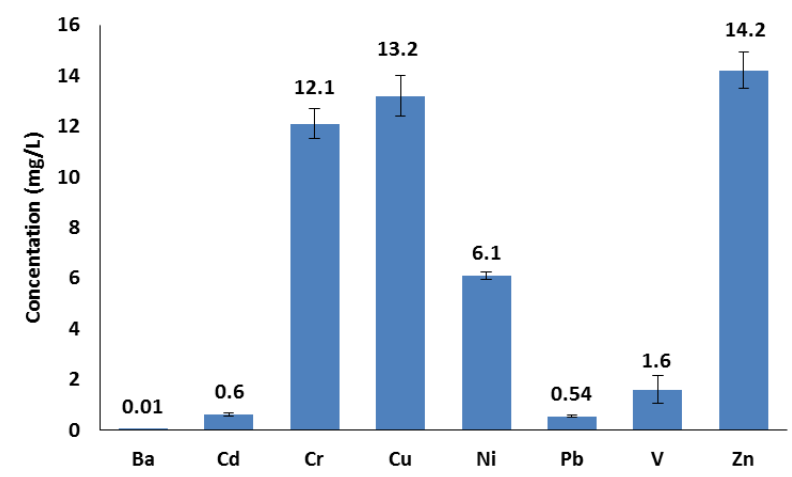

Figure 2. Heavy metal concentration in slurry sludge.

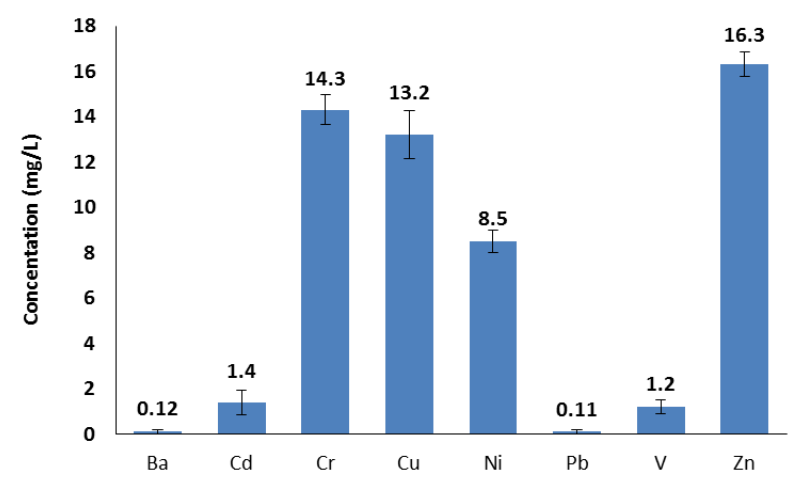

Figure 3. Heavy metal concentration in dried sludge.

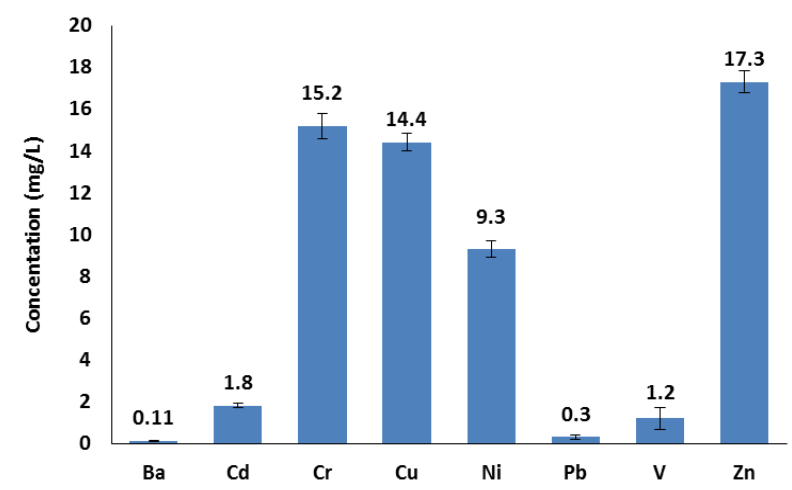

Figure 4. Heavy metal concentration in landfill. 


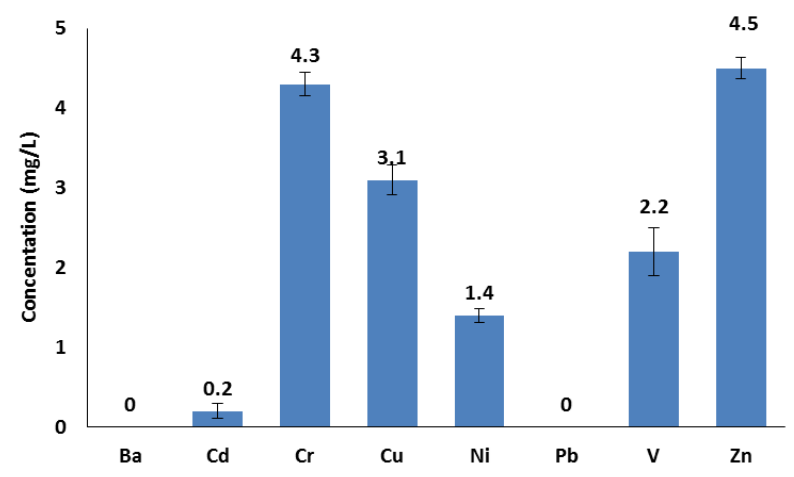

Figure 5. Heavy metal concentrations in underground water.

the environment.

Based on this study, it appears that the major source of heavy metal contamination is from TSE and sludge. There is a strong indication that the heavy metals in Oman are spreading rapidly throughout different habitats because of rapid increase in population and industries (Al-Bahry et al., 2011, Al-Musharafi et al., 2012, 2013a, 2013b, 2013c; Al-Rawahi et al., 2007).

In this study, sewage water, slurry sludge, dried sludge, landfill and underground water were examined to evaluate the heavy metal contamination. The data revealed that there is widespread heavy metal contamination in the study areas. It was also found that water and sewage samples were contaminated by heavy metals caused by STP from the industrial effluents and was correlated with sludge and underground water. STPs used from industries had higher concentration compared to STP from residential communities, hospitals and public institutions (Al-Musharafi et al., 2012).

Based on the present data, it was revealed that heavy metals contaminated underground water but with less intensity than the rest of sampling areas. It was also reported that heavy metals accumulated in soil can penetrate into the underground water (Al-Musharafi et al., 2012; Skeat, 1969).

Heavy metal contamination resulting from industrial effluents was reported in snails, grass roots, TSE and sediment (AlMusharafi et al., 2013a). In addition, heavy metal contaminations in different habitats were found in Oman (Al-Bahry et al., 2011; Al-Musharafi et al., 2013a).

Further investigations concerning heavy metal pollution in different areas in Oman are needed in order to compare the degree of heavy metal contamination in the various regions.

\section{References}

Al-Bahry, S. N., Mahmoud, I., Al-Rawahi, S., \& Paulson, J. (2011). Egg Contamination as an Indicator of Environmental Health. New York, USA: Nova Science Publisher, Inc.

Al-Musharafi, S. K., Mahmoud, I. Y., \& Al-Bahry, S. N. (2013c). Contamination of Marine Fish by Heavy Metals from Coastal Sewage Treated Effluent Runoff. In The Third Asian Conference on Sustainability, Energy and the Environment. Acsee 2013 (pp. 100-107). Osaka, Japan: The International Academic Forum (IAFOR).

Al-Musharafi, S. K., Mahmoud, I. Y., \& Al-Bahry, S. N. (2013b). Heavy Metals Infiltration from Sewage Treated Effluent into Soil and Tomato pLants. IPCBEE, 50, 16-25.

Al-Musharafi, S. K., Mahmoud, I. Y., \& Al-Bahry, S. N. (2012). Heavy Metal Contamination from Treated Sewage Effluents. In Proceedings of $11^{\text {th }}$ International Conference on Modelling, Monitoring and Management of Water Pollution (pp. 381-389). Vol. 164. New Forest, UK: WIT Transactions on Ecology and the Environment.

Al-Musharafi, S. K., Mahmoud, I. Y., \& Al-Bahry, S. N. (2013a). Heavy Metal Pollution from Treated Sewage Effluent. Procedia APCBEES, 5, 344-348. http://dx.doi.org/10.1016/j.apcbee.2013.05.059

Al-Rawahy, S. H., Alkindi, A. Y., Elshafie, A. E., Mahmoud, I. Y., Al-Bahry, S. N., Al-siyabi, S., Al Mansori, M., \& Al Kiyumi, A. (2007). Accumulation of Metals in the Egg Yolk and Liver of Hatchling of Green Turtles Chelonia mydas at Ras Al Hadd, Sultanate of Oman. Journal of Biological Sciences, 7, 925-930. http://dx.doi.org/10.3923/jbs.2007.925.930

APHA/AWWA/WEF (American Public Health Association/American Water Works Association/Water Environment Federation (1998). Standard Methods for the Examination of Water and Wastewater (20th ed.). Washington DC: American Public Health Association/American Water Works Association/Water Environment Federation. Baltimore, Maryland, USA: United Book Press Inc. 
Carter, J. T., Rice, E. W., Buchberger, S. G., \& Lee, Y. (2000). Relationship between Level of Heterotrophic Bacteria and Water Quality Parameters in a Drinking Water Distribution System. Water Research, 34, 1495-1502. http://dx.doi.org/10.1016/S0043-1354(99)00310-3

Fent, K. (1996). Ecotoxicology of Organotin Compounds. Critical Reviews in Toxicology, 26, 1-117. http://dx.doi.org/10.3109/10408449609089891

Harper, E. R., St Leger, J. A., Westberg, J. A., Mazzaro, L., Schmitt, T., Reidarson, T. H., Tucker, M., Cross, D. H., \& Puschner, B. (2007). Tissue Heavy Metal Concentrations of Stranded California Sea Lions (Zalophus californianus) in Southern California. Environmental Pollution, 147, 677-682. http://dx.doi.org/10.1016/j.envpol.2006.09.013

Jeffree, R. A., Warnau, M., Oberhansli, F., \& Teyssie, J. (2006). Bioaccumulation of Heavy Metals and Radionuclides from Seawater by Encased Embryos of the Spotted Dogfish Scyliorhinus canicula. Marine Pollution Bulletin, 52, 1278-1286. http://dx.doi.org/10.1016/j.marpolbul.2006.03.015

Kannan, K., Agusa, T., Perrotta, E., Thomas, N. J., \& Tanabe, S. (2006). Comparison of Trace Element Concentrations in Livers of Diseased, Emaciated and Non-Diseased Southern Sea Otters from the California Coast. Chemosphere, 65, 2160-2167. http://dx.doi.org/10.1016/j.chemosphere.2006.06.003

Kojadinovic, J., Potier, M., Le, Corre, M., Cosson, R. P., \& Bustamante, P. (2007). Bioaccumulation of Trace Elements in Pelagic Fish from the Western Indian Ocean. Environmental Pollution, 146, 548-566.

http://dx.doi.org/10.1016/j.envpol.2006.07.015

Mapanda, F., Mangwayana, E. N., Giller, K. E., \& Nyamangara, J. (2007). Uptake of Heavy Metals by Vegetables Irrigated Using Wastewater and the Subsequent Risks in Harare, Zimbabwe. Physics and Chemistry of the Earth, 32, 1399-1405. http://dx.doi.org/10.1016/j.pce.2007.07.046

Mishra, S., Rakash, Dwivedi, S. P., \& Singh, R. B. (2010). A Review on Epigenetic Effect of Heavy Metal Carcinogens on Human Health. The Open Nutraceuticals Journal, 3, 188-193. http://dx.doi.org/10.2174/1876396001003010188

Moor, C., Lymberopoulou, T., \& Volker J. Dietrich, V. (2001). Determination of Heavy Metals in Soils, Sediments and Geological Materials by ICP-AES and ICP-MS. Microchimica Acta, 136, 123-128. http://dx.doi.org/10.1007/s006040170041

Skeat, W. O. (1969). Manual of British Water Engineering Practice. Vol. b: Water Quality and Treatment. London: The Institution of Water Engineers.

Storelli, M. M., Barone, G., Storelli, A., \& Marcotrigiano, G. O. (2008). Total and Subcellular Distribution of Trace Elements (Cd, $\mathrm{Cu}$ and $\mathrm{Zn}$ ) in the Liver and Kidney of Green Turtles (Chelonia mydas) from the Mediterranean Sea. Chemosphere, 70, 908-913. http://dx.doi.org/10.1016/j.chemosphere.2007.06.069

Zauke, G. P., Clason, B., Savinov, V. M., \& Savinova, T. (2003). Heavy Metals of Inshore Benthic Invertebrates from the Barents Sea. The Science of the Total Environment, 306, 99-110. http://dx.doi.org/10.1016/S0048-9697(02)00487-4 